\title{
Bone anchor fixation method of an incarcerated Petit hernia in an elderly lady: Optimal management of a rare case
}

\author{
Mohamed Abdrabboh, Mohamed A. Mohamed, Adel Elmoghrabi, Kristoffer Wong, Michael McCann \\ Hurley Medical Center, One Hurley Plaza - 7W Trauma Services, Flint, MI, United States
}

Received: June 27, 2016

DOI: $10.5430 /$ css.v2n4p36
Accepted: August 11, $2016 \quad$ Online Published: August 23, 2016

URL: http://dx.doi.org/10.5430/css.v2n4p36

\begin{abstract}
Background: The first reported lumbar hernia was in 1731. Since then, only about 300 cases have been reported in the literature. Approximately $20 \%$ of lumbar hernias are congenital and the remainder are acquired. They commonly occur in males, more frequently on the left side, and the majority are reported in the sixth-to-seventh decade of life. Based on the anatomical defect, lumbar hernias are classified into two types: superior (Grynfeltt-Lesshaft) and Inferior (Petit). Petit hernias are less common and their proximity to bone can make them more difficult to repair. Several methods for optimal repair have been proposed. Since 2004, only 7 reports advocated surgical management using the bone anchor fixation method.

Case description: A 79-year-old obese female presented to the outpatient clinic with a 1-year history of moderate right lumbar pain. Examination revealed a tender bulge in the posterior lumbar region. CT of the abdomen \& pelvis revealed a $6.6 \mathrm{~cm} \times 7.4 \mathrm{~cm}$ defect in the right posterolateral abdomen incorporating parts of the right ascending colon. She was diagnosed with right-sided Petit lumbar hernia and underwent an open hernia repair with iliac crest anchor fixation and mesh implantation. The postoperative course was uneventful and the patient was discharged in a stable condition.

Conclusions: Lumbar hernias represent a rare clinical phenomenon, especially in females. A protruding mass in the lumbar region with localized abdominal pain and radiographic evidence of posterior abdominal wall defect should raise suspicion for a lumbar hernia. Predisposing factors such as old age, obesity and conditions that increase intra-abdominal pressure increase the risk of lumbar hernia. There is a current dilemma centered on the optimal type of surgical approach and repair technique. In our case, an open repair using the bone anchor fixation technique led to excellent results.
\end{abstract}

Key Words: Hernia, Lumbar, Petit, Bone anchor

\section{INTRODUCTION}

Lumbar hernias are rarely reported. ${ }^{[1]}$ The first reported case was in 1731, and since then, only about 300 cases have been reported in the English literature. ${ }^{[2]}$ Lumbar hernias occur through defects in the posterior-lateral abdominal wall. Approximately two-thirds of all documented lumbar hernia cases occur in males. ${ }^{[3]}$ Lumbar hernias are twice as com- mon on the left side, and the majority of reported cases are in the sixth-to-seventh decade of life. ${ }^{[4]}$ Several methods of optimal repair have been proposed with a current controversy centered on the optimal surgical management. This report demonstrates a successful, safe, and stable open repair of a spontaneous right-sided Petit hernia using the bone anchor fixation technique.

*Correspondence: Mohamed A. Mohamed; Email: mmohame4@hurleymc.com; Address: Hurley Medical Center, One Hurley Plaza - 7W Trauma Services, One Hurley Plaza, Flint, MI 48439, United States. 
The etiology is either congenital (20\%) or acquired (80\%), for a majority of the reported cases. ${ }^{[5]}$ Although only $25 \%$ with the latter occurring either: spontaneously, secondary to trauma, past surgical incisions, or due to infections to the lumbar region. ${ }^{[2,5]}$ Based on the anatomical defect, lumbar hernias are classified into two types: Superior (GrynfelttLesshaft) and Inferior (Petit), being named after the individuals who discovered them. ${ }^{[6]}$ Superior lumbar hernias account of spontaneous lumbar hernias become incarcerated, lumbar hernias should be repaired as soon as possible to prevent possible strangulation and death of abdominal contents. ${ }^{[4]}$ As a result, it is important to rule out a diagnosis of lumbar hernia, especially in the face of an entity that is known for being difficult to diagnose. ${ }^{[4]}$
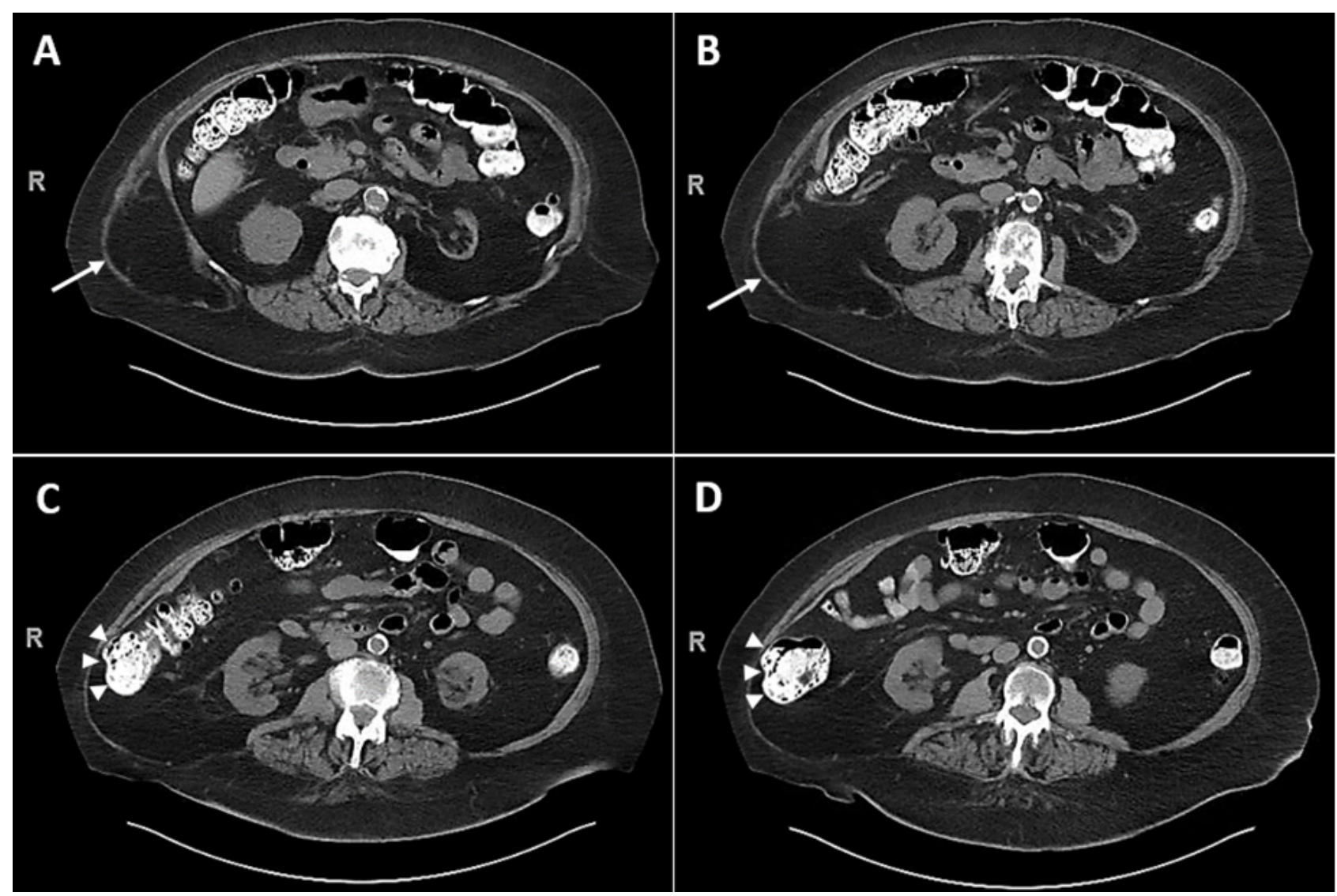

Figure 1. CT of the abdomen with contrast (axial view) showing a right sided lumbar hernia (white arrows) containing bowel loops (white arrow heads)

\section{CASE PRESentation}

A 79-year-old obese female (body mass index [BMI] of 39.5) presented to the outpatient clinic with a 1-year history of moderate, progressive, non-radiating, right lumbar pain that was aggravated by activity. The patient initially ignored the pain which gradually became bothersome over time. There were no complaints of vomiting or constipation, and no history of trauma, heavy lifting or other relevant predisposing factors. Past medical and social history were irrelevant. Physical examination revealed a tender, fluctuant, mobile, and partially reducible bulge in the right posterior lumbar region measuring about $5 \mathrm{~cm} \times 5 \mathrm{~cm}$. Abdominal examination revealed a soft and non-distended abdomen with no bulges, tenderness or guarding. CT of the abdomen \& pelvis without contrast revealed a

Published by Sciedu Press
$6.6 \mathrm{~cm} \times 7.4 \mathrm{~cm}$ defect in the right posterior-lateral abdomen incorporating parts of the right ascending colon (see Figures 1 and 2). The patient was diagnosed with right-sided Petit lumbar hernia and planned for operative management.

An open hernia repair with iliac crest anchor fixation and mesh implantation were performed. A 10 inch $\times 14$ inch Bard ${ }^{\circledR}$ monofilament polypropylene mesh was tacked anteriorly on top of the pelvic brim four times using the Juggernaut suture anchors. The mesh was tacked through the iliopsoas muscle, lifted around the patient's right flank in a taco shape and up to the $11^{\text {th }}$ rib for provision of better stability to the retroperitoneal fascia. The postoperative course was uneventful and the patient was discharged in a stable condition on the fourth postoperative day. Within 
the course of outpatient follow up, the patient developed a $7.4 \mathrm{~cm} \times 6.6 \mathrm{~cm} \times 7.6 \mathrm{~cm}$ seroma two months after the operation, which was drained and resolved uneventfully. The patient continues to follow up and is doing well with no evidence of hernia or seroma recurrence at 5 months postoperatively.
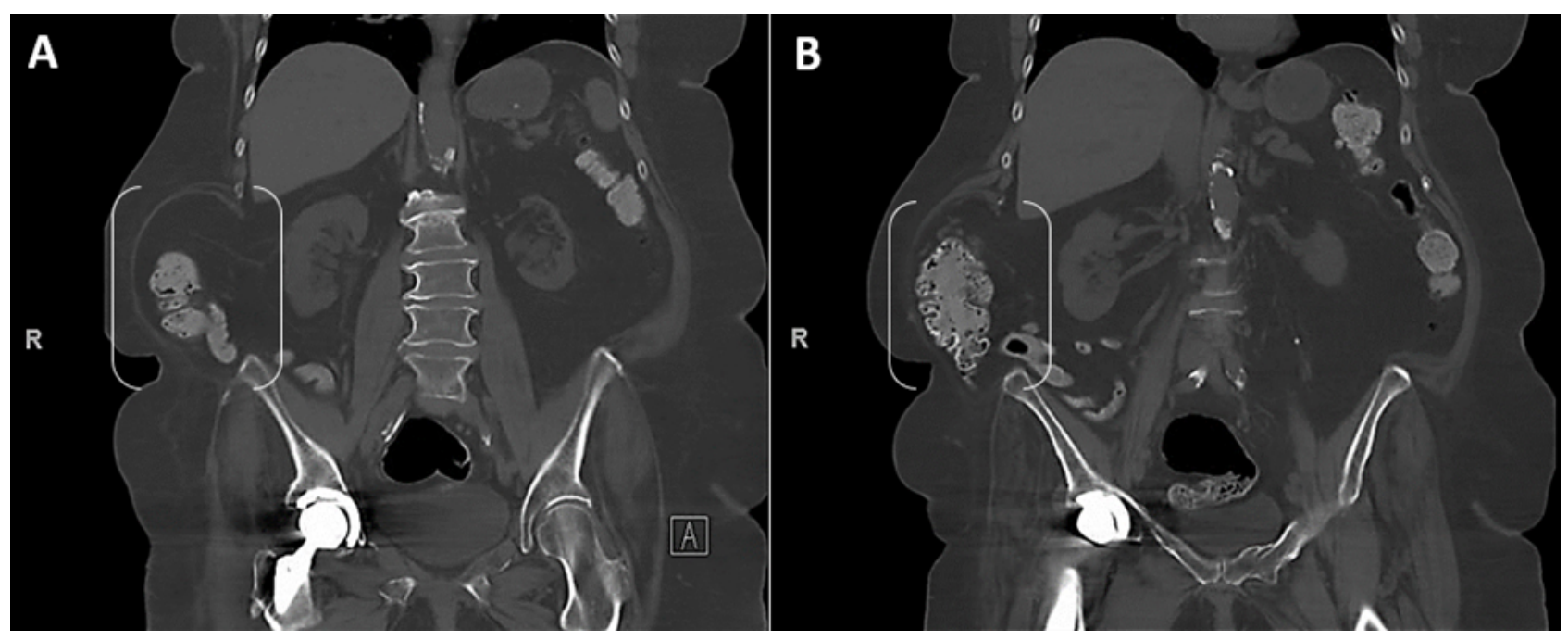

Figure 2. CT of the abdomen with contrast (coronal section) showing a right sided lumbar hernia containing bowel loops

\section{Discussion}

Lumbar hernias represent a rare clinical entity, especially in elderly females. Of the different types of lumbar hernias, the inferior (Petit) lumbar hernia is quite uncommon representing less than $1 \%$ of all abdominal wall hernias. ${ }^{[7]}$ Due to its rarity in occurrence, proximity to bone, and the reduced strength of the retroperitoneal fascia; deciding on the optimal strategy for repairing inferior lumbar hernias may be challenging. ${ }^{[8]}$ There is no current gold standard for the method of repair. Multiple repair techniques have been suggested, including but not limited to: open or laparoscopic repairs, utilizing nearby muscle groups for flaps, primary closure, and double layer mesh attachments. ${ }^{[8]}$

Superior lumbar hernias are located below the $12^{\text {th }}$ rib and are laterally bound by the latissimus dorsi, quadratus lumborum, and internal oblique muscles. The floor of the defect is formed by the transversalis fascia and the aponeurosis of the transversus abdominis muscle (see Figure $3 \mathrm{~A}$ ). ${ }^{[6]}$ On the other hand, inferior lumbar hernias are located just above the iliac crest and are bounded by the external oblique and latissimus dorsi muscles, with the internal oblique muscle representing the floor of the defect (see Figure 3B). ${ }^{[6]}$ The proximity of inferior lumbar hernias to bone can create technical difficulty for a surgeon attempting a stable repair.

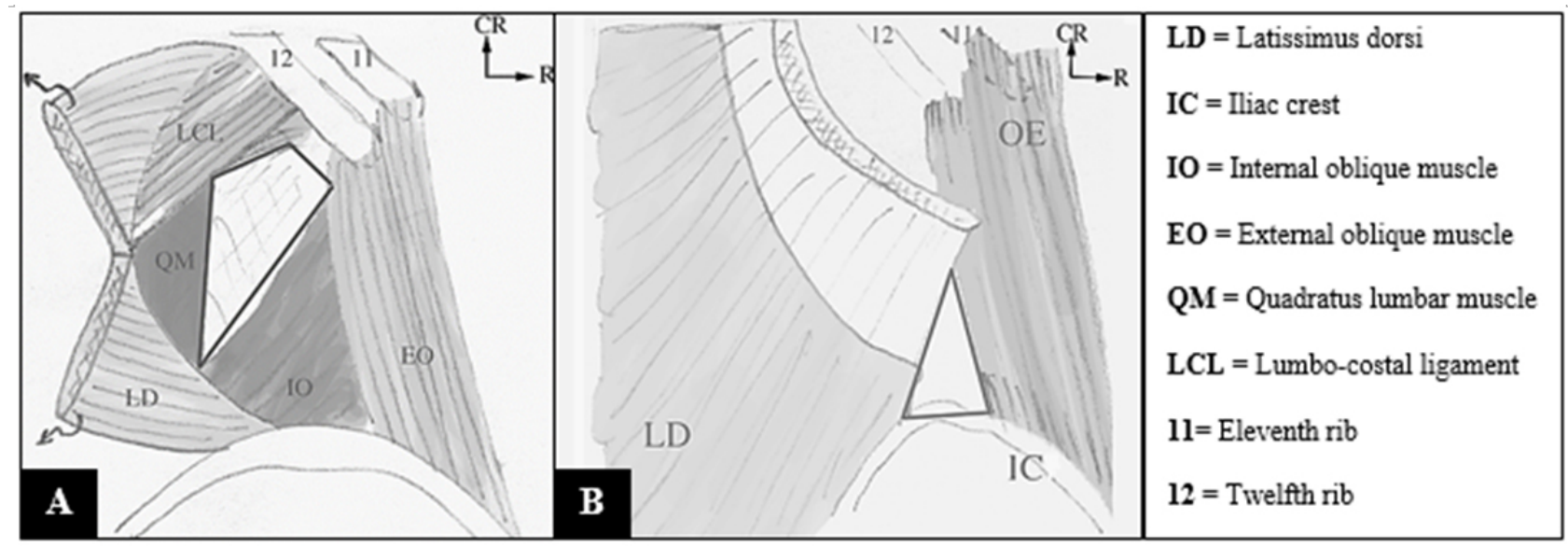

Figure 3. (A) Right Grynfeltt-Lesshaft (superior) hernia anatomy; (B) Right Petit (inferior) hernia anatomy Adapted from Armstrong $O$ et al. ${ }^{[6]}$ 
Diagnosis of lumbar hernia may be challenging as patients may be asymptomatic or present with nonspecific signs and symptoms. A typical presentation includes a protruding mass in the lumbar region with variation in pain and discomfort. However, palpation of a mass may be difficult, especially in obese patients. Old age resulting in loss of abdominal fatty tissue may represent a predisposing factor for herniation in the posterior abdominal wall. Obesity and other conditions associated with increased intra-abdominal pressure such as pregnancy, may also increase the risk for lumbar hernia. ${ }^{[4]}$ If the hernia contains incarcerated abdominal contents, patients may present with symptoms of intestinal obstruction, including but not limited to nausea, vomiting, and constipation. ${ }^{[9]}$ Differential diagnosis includes: hematoma, abscess, lipoma, muscle strain, panniculitis, and renal tumors. CT of the abdomen with or without contrast is the preferred diagnostic modality to adequately visualize the anatomy of the defect in the peritoneal fascia and the herniated sac of abdominal contents. Surgery is usually the recommended treatment. ${ }^{[1]}$

An open procedure is the classic method of repair for lumbar hernias, however, laparoscopic methods are more recently being described and recommended as being the best approach due to the well-known benefits of minimally invasive surgery: shorter length of hospital stay, less pain, and fewer wound complications. ${ }^{[1,4]}$ A prospective nonrandomized study comparing open versus laparoscopic repair of 16 patients who underwent operation for lumbar hernias revealed one hernia recurrence with the open approach and no recurrences with the laparoscopic approach. ${ }^{[1]}$ The study also revealed a significant increase in postoperative morbidity in the open approach, however, in the laparoscopic approach, there was a higher incidence of intraoperative complications (two hematomas and one inferior epigastric artery lesion). ${ }^{[1]}$ It has been shown that repair under controlled tension, usually required for providing a durable and recurrence-free repair, may not be feasible with the laparoscopic approach especially with the relative weakness of the surrounding fascial layers of the posterior abdomen. ${ }^{[8]}$ In light of this fact and the current controversy in the management of lumbar hernias, our decision was made to perform an open repair. As presented in our case, the procedure was uneventful and with no peri-operative complications encountered except for the seroma that developed postoperatively and was treated successfully. Moreno-Egea et al. ${ }^{[1]}$ reported no intraoperative complications among patients that were treated with an open technique, however, there was an increase in the number of hernia recurrences postoperatively. To date, no hernia recurrence has been appreciated in our case.

We conducted a literature review on lumbar hernia repairs using the bone anchor fixation technique and found, besides this report, only 2 studies $^{[10,11]}$ and 5 case reports ${ }^{[12-16]}$ since 2004. Table 1 outlines the surgical approach used in each of the reports. None of the post-operative complications were specifically relevant to the repair technique. Nonetheless in the study by Blair et al., ${ }^{[10]} 20$ patients with suprapubic, para-iliac and lumbar hernias who underwent bone anchor mesh fixation were evaluated and among those, two seromas and wound dehiscence were reported post-operatively but with ambiguity on the associated hernia type.

Table 1. Summary of studies/case reports of lumbar hernia with bone anchor fixation

\begin{tabular}{|c|c|c|c|c|c|}
\hline $\begin{array}{l}\text { Author/Year published/ } \\
\text { description }\end{array}$ & Surgical approach & $\begin{array}{l}\text { No. of cases with } \\
\text { lumbar hernia }\end{array}$ & $\begin{array}{l}\text { Post-operative } \\
\text { complications }\end{array}$ & $\begin{array}{l}\text { Hernia } \\
\text { recurrence rate }\end{array}$ & Follow-up time \\
\hline $\begin{array}{l}\text { Patten et al.(2004) } \\
\text { Case report }\end{array}$ & Laparoscopic & 2 & None & $0 \%$ & Unspecified \\
\hline $\begin{array}{l}\text { Salameh and Salloum (2004) } \\
\text { Case report }\end{array}$ & Laparoscopic & 1 & Atrial fibrillation & $0 \%$ & Unspecified \\
\hline $\begin{array}{l}\text { Carbonell et al.(2005) } \\
\text { Retrospective review }\end{array}$ & Open & 10 & $\begin{array}{l}\text { Surgery site "discomfort" } \\
\text { in one case }\end{array}$ & $0 \%$ & 40 months \\
\hline $\begin{array}{l}\text { Bathla et al.(2011) } \\
\text { Case report }\end{array}$ & $\begin{array}{l}\text { Combined open and } \\
\text { laparoscopic }\end{array}$ & 2 & None & $0 \%$ & 9 months \\
\hline $\begin{array}{l}\text { Ho and Dakin (2011) } \\
\text { Case report }\end{array}$ & Laparoscopic & 1 & None & $0 \%$ & Unspecified \\
\hline $\begin{array}{l}\text { Links and Berney (2011) } \\
\text { Case report }\end{array}$ & Laparoscopic & 1 & None & $0 \%$ & 12 months \\
\hline $\begin{array}{l}\text { Blair et al.(2015) } \\
\text { Prospective study }\end{array}$ & Open & 10 & Unclear from the study & $0 \%$ & 24 months \\
\hline $\begin{array}{l}\text { Abdrabboh et al.* (2016) } \\
\text { Case report }\end{array}$ & Open & 1 & None & $0 \%$ & 5 months \\
\hline
\end{tabular}

${ }^{*}$ This case report 
Several methods for optimal repair of lumbar hernias have been proposed. The different available repair options that have been reported in addition to bone anchor fixation include using local tissue and fascia flaps, primary mesh closure, and double layer mesh repair, with each method having various reports of successful outcomes with respect to rate of hernia recurrence and operative complications. ${ }^{[17-19]}$ Nonetheless, specific selection criteria for any of the aforementioned methods over the other are nonexistent. ${ }^{[8]}$ In our case, we decided to perform repair using bone anchor fixa- tion because in addition to reports of successful outcomes (see Table 1), using structural support of neighboring bone may have provided superiority in stability of the repair over other methods. With a current dilemma centered on the optimal type of surgical approach (open versus laparoscopic), we report the successful use of bone suture anchors using the open surgical approach, a repair that in our case was both safe and effective.

\section{CONFlicts of InTEREST Disclosure}

The authors declare they have no conflicts of interest.

\section{REFERENCES}

[1] Moreno-Egea A, Torralba-Martinez J, Morales G, et al. Open vs laparoscopic repair of secondary lumbar hernias: a prospective nonrandomized study. Surgical Endoscopy. 2005; 19(2): 184-187. PMid: 15573242. http://dx.doi.org/10.1007/s00464-004 $-9067-7$

[2] Stamatiou D, Skandalakis JE, Skandalakis LJ, et al. Lumbar Hernia: Surgical Anatomy, Embryology, and Technique of Repair. Am Surg 2009; 75(3): 202-7. PMid: 19350853.

[3] Zhou X, Nve J, Chen G. Lumbar hernia: Clinical analysis of 11 cases Hernia. 2004; 8(3). PMid: 15221643. http://dx.doi.org/10.10 07/s10029-004-0230-9

[4] Suarez S, Hernandez J. Laparoscopic repair of a lumbar hernia: report of a case and extensive review of the literature. Surgical Endoscopy. 2013; 27(9): 3421-3429. PMid: 23636518. http: //dx.doi.org/10.1007/s00464-013-2884-9

[5] Sundaramurthy S, Suresh H, Anirudh A, et al. Primary lumbar hernia: A rarely encountered hernia. International Journal of Surgery Case eports. 2016; 20: 53-56. PMid: 26812667. http://dx.doi.org/1 $0.1016 /$ j.ijscr.2015.09.041

[6] Armstrong O, Hamel A, Grignon B, et al. Lumbar hernia: anatomical basis and clinical aspects. Surgical and Radiologic Anatomy. 2008; 30(7): 533-537. PMid: 18553051. http://dx.doi.org/10.1007 /s00276-008-0361-2

[7] Fontoura RD, Araújo ES, Oliveira GA, et al. Spontaneous bilateral Petit hernia. Revista Do Colégio Brasileiro De Cirurgiões. 2011; 38(5): 369-70. PMid: 22124652. http://dx.doi.org/10.1590 /S0100-69912011000500016

[8] Cesar D, Valadão M, Murrahe R. Grynfelt hernia: case report and literature review. Hernia. 2010; 16(1): 107-111. PMid: 20821030. http://dx.doi.org/10.1007/s10029-010-0722-8

[9] Jang T, Schindler D, Kaji A. Predictive value of signs and symptoms for small bowel obstruction in patients with prior surgery. Emergency Medicine Journal. 2011; 29(9): 769-770. PMid: 21212228. http://dx.doi.org/10.1136/emj.2010.100594

[10] Blair LJ, Cox TC, Huntington CR, et al. Bone Anchor Fixation in Abdominal Wall Reconstruction: A Useful Adjunct in Suprapubic and Para-iliac Hernia Repair. Am Surg. 2015 Jul; 81(7): 693-7. PMid: 26140889.

[11] Carbonell A, Kercher K, Sigmon L, et al. A novel technique of lumbar hernia repair using bone anchor fixation. Hernia. 2004; 9(1): 22-25. PMid: 15365883. http://dx.doi.org/10.1007/s1002 9-004-0276-8

[12] Salameh JR, Salloum EJ. Lumbar Incisional Hernias: Diagnostic and Management Dilemma. Journal of the Society of Laparoendoscopic Surgeons. 2004; 8(4): 391-394. PMid: 15554289.

[13] Ho VDakin G. Laparoscopic lumbar hernia repair with bone anchor fixation. Surgical Endoscopy. 2010; 25(5): 1665-1665. PMid: 21046160.

[14] Links DJR, Berney CR. Traumatic lumbar hernia repair: a laparoscopic technique for mesh fixation with an iliac crest suture anchor. Hernia. 2010; 15(6): 691-693. PMid: 20803044. http: //dx.doi.org/10.1007/s10029-010-0716-6

[15] Bathla L, Davies E, Fitzgibbons R, et al. Timing of traumatic lumbar hernia repair: is delayed repair safe? Report of two cases and review of the literature. Hernia. 2010; 15(2): 205-209. PMid: 20069439. http://dx.doi.org/10.1007/s10029-009-0625-8

[16] Patten L, Awad S, Berger D, et al. A novel technique for the repair of lumbar hernias after iliac crest bone harvest. The American Journal of Surgery. 2004; 188(1): 85-88. PMid: 15219491. http://dx.doi.org/10.1016/j.amjsurg. 2003.10.026

[17] Heniford B. Laparoscopic Inferior and Superior Lumbar Hernia Repair. Arch Surg. 1997; 132(10): 1141. PMid: 9336516. http: //dx.doi.org/10.1001/archsurg.1997.01430340095017

[18] Sutherland RGerow R. Hernia After Dorsal Incision Into Lumbar Region: A Case Report and Review of Pathogenesis and Treatment. The Journal of Urology. 1995; 153(2): 382-384. http: //dx.doi.org/10.1097/00005392-199502000-00026

[19] Ploneda-Valencia C, Cordero-Estrada E, Casta-eda-González L, et al. Grynfelt-Lesshaft hernia a case report and review of the literature. Annals of Medicine and Surgery. 2016; 7: 104-106. PMid: 27144007. http://dx.doi.org/10.1016/j.amsu.2016.04.002 